\title{
Phylogeographic Investigation of an Endangered Longhorn Beetle, Callipogon relictus (Coleoptera: Cerambycidae), in Northeast Asia: Implications for Future Restoration in Korea
}

\author{
Ji Hyoun Kang ${ }^{1,+}{ }^{\circ}$, Dae-Am $\mathrm{Yi}^{2,+}{ }^{\text {, Alexander V. Kuprin }}{ }^{3 \oplus}$, Changdo Han ${ }^{4}$ and Yeon Jae Bae ${ }^{5, *}$ \\ 1 Korean Entomological Institute, Korea University, Seoul 02841, Korea; jihyounkang@korea.ac.kr \\ 2 Research Center of Natural Monument Insects, Yeongwol Insect Museum, Yeongwol 26210, Korea; \\ 2bigstone@korea.ac.kr \\ 3 Federal Scientific Center of the East Asia Terrestrial Biodiversity, Far Eastern Branch of the Russian Academy \\ of Sciences, 690022 Vladivostok, Russia; kyprins@mail.ru \\ 4 Wildlife Research Center, Korea University, Ogawa-chô, Kodaira City, Tokyo 187-0032, Japan; \\ changdo0429@hotmail.co.jp \\ 5 Division of Environmental Science and Ecological Engineering, Korea University, Seoul 02841, Korea \\ * Correspondence: yjbae@korea.ac.kr; Tel.: +82-0(2)-3290-3408 \\ + These authors contributed equally to this work.
}

Citation: Kang, J.H.; Yi, D.-A.; Kuprin, A.V.; Han, C.; Bae, Y.J. Phylogeographic Investigation of an Endangered Longhorn Beetle, Callipogon relictus (Coleoptera: Cerambycidae), in Northeast Asia: Implications for Future Restoration in Korea. Insects 2021, 12, 555. https:// doi.org/10.3390/insects12060555

Received: 12 April 2021

Accepted: 7 June 2021

Published: 15 June 2021

Publisher's Note: MDPI stays neutral with regard to jurisdictional claims in published maps and institutional affiliations.

Copyright: (c) 2021 by the authors. Licensee MDPI, Basel, Switzerland. This article is an open access article distributed under the terms and conditions of the Creative Commons Attribution (CC BY) license (https:// creativecommons.org/licenses/by/ $4.0 /)$.
Simple Summary: The critically endangered Callipogon relictus is one of the largest longhorn beetle species and also the only remnant species of the genus Callipogon found in the Palearctic region. Knowledge of the phylogeographic history and current conservational status is essential to understand its unique distribution and to establish efficient conservation strategies. We studied the phylogeographical pattern and genetic diversity of $C$. relictus from almost its entire geographical range. The level of genetic diversity and divergence of $C$. relictus from the known distributions in four regions in Russia, China, North Korea, and South Korea using two mitochondrial markers (COI and COII) revealed that genetic diversity lies within the range of intraspecific levels. Relatively high genetic diversity with no distinct phylogeographic structures indicates that the wide range of current fragmented populations might be the remnant of genetically diverse populations in the past. The results of our phylogenetic and population genetic analyses suggest that $C$. relictus populations surveyed in the present study can be used as a "source" for a future restoration and conservation program. The findings of the genetic characteristics and phylogeographic history of C. relictus will help to establish effective conservation strategies for this endangered longhorn beetle species in Northeast Asia.

Abstract: The longhorn beetle, Callipogon (Eoxenus) relictus Semenov, is the only remnant species found in the Palearctic region, while all other Callipogon species are distributed mainly in Central America and partly in South America. This species has been placed in the first category (as 'critically endangered') of the Red Data Book in Russia and designated as one of the top-priority target species among all endangered invertebrate species for restoration in South Korea since 2006. Although its restricted distribution in Northeast Asia with a high conservational value has been highlighted, genetic features of $C$. relictus from different geographic regions remain unexplored. We first investigated the level of genetic diversity and phylogeographic patterns of $C$. relictus to evaluate the current conservational status and the feasibility of the implementation of a restoration program. The average genetic divergence of mitochondrial gene COI based on Kimura-2-parameter distance among the four regions in Russia, China, North Korea, and South Korea was 2.2\%, which lies within the range of intraspecific levels. However, two separate clades with 3.8\% divergence were identified, despite no geographical clustering of haplotypes. The linear pattern of the haplotype network with a high level of haplotype and nucleotide diversities suggests that the wide range of currently fragmented populations might be the remnant of genetically diverse populations in the past. This study will provide crucial information on the genetic characteristics and phylogeographic history of C. relictus, which will help to establish conservation strategies for this cherished insect species in Northeast Asia. 
Keywords: COI; COII; endangered species; longhorn beetle; restoration; saproxylic insect

\section{Introduction}

The critically endangered Callipogon relictus is one of the largest, most charismatic longhorn beetle species and also the only remnant species of genus Callipogon AudinetServille, 1832, found in the Palearctic entomo-fauna (Figure 1). Other Callipogon species are distributed mainly in Central America and partly in South America [1-4]. In Asia, C. relictus is found only in the Siberian part of the Palearctic realm comprising far-east Russia, northeast China, North Korea, and the northern part of South Korea [5-8]. The boundaries of the known habitats encompass a distance of approximately $1400 \mathrm{~km}$ north to south and (app.) $1800 \mathrm{~km}$ east to west, covering almost eleven degrees of latitude (from $48^{\circ} 37^{\prime} \mathrm{N}$ to $37^{\circ} 44^{\prime} \mathrm{N}$ ) and twelve degrees of longitude (from $135^{\circ} 07^{\prime} \mathrm{E}$ to $123^{\circ} 27^{\prime} \mathrm{E}$ ) (Figure 2). Among the four countries, in both Russia and South Korea, C. relictus was placed in the first category of the Red Data Book and it is protected by law $[7,9,10]$. In South Korea, it is not only listed as an endangered species but is also regarded as a national natural monument (no. 218); even the dead body of C. relictus is required to be registered under the regulation of Cultural Properties Protection Law.

Callipogon relictus, a saproxylic longhorn beetle, inhabits mixed and deciduous forests but not temperate coniferous forests; the beetles feed on the rotten logs of ancient or veteran broadleaf trees such as Ulmus davidiana var. japonica (Ulmaceae), Quercus mongolica (Fagaceae), Quercus aliena, Quercus serrata, Carpinus laxiflora (Betulaceae), etc. [7,10,12-17]. The wood-boring larva is a polyphagous internal feeder, which goes through a five- to seven-year developmental period inside rotten timber [15]. Until the beginning of the 1950s, there were two major populations of $C$. relictus in South Korea; one in the Gwangneung Forest in Gyeonggi-do (province) and the other in Chuncheon in Gangwon-do, which is located $100 \mathrm{~km}$ to the east of the Gwangneung Forest, almost in the same latitude $\left(37^{\circ} \mathrm{N}\right)$ [14]. Unfortunately, the Chuncheon site was destroyed during the Korean War (1950-1953) and then submerged by the immense Soyang Dam built in 1967. Recently, distribution of $C$. relictus in the Gwangneung forest and a new location in Yangyang have been reported in Korea during four consecutive years from 2007 to 2017 [18].

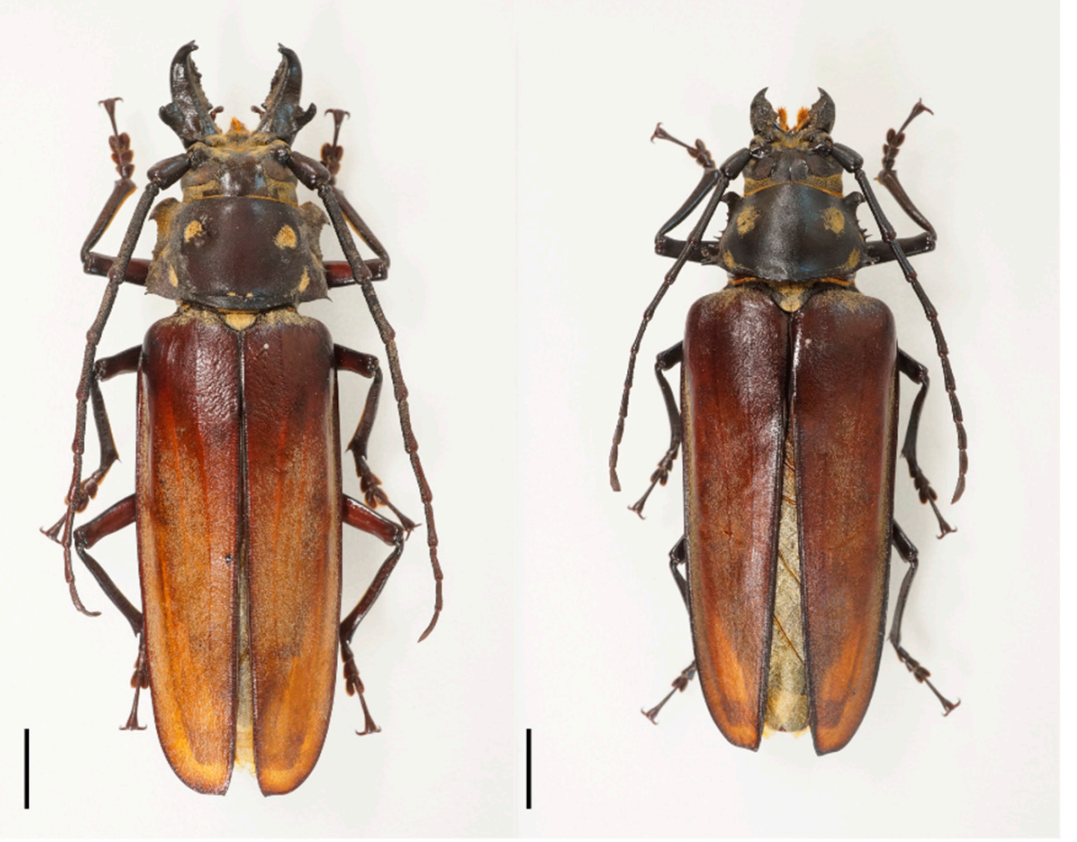

Figure 1. Habitus of Callipogon relictus, male (left) and female (right) (scale $10 \mathrm{~mm}$ ). 


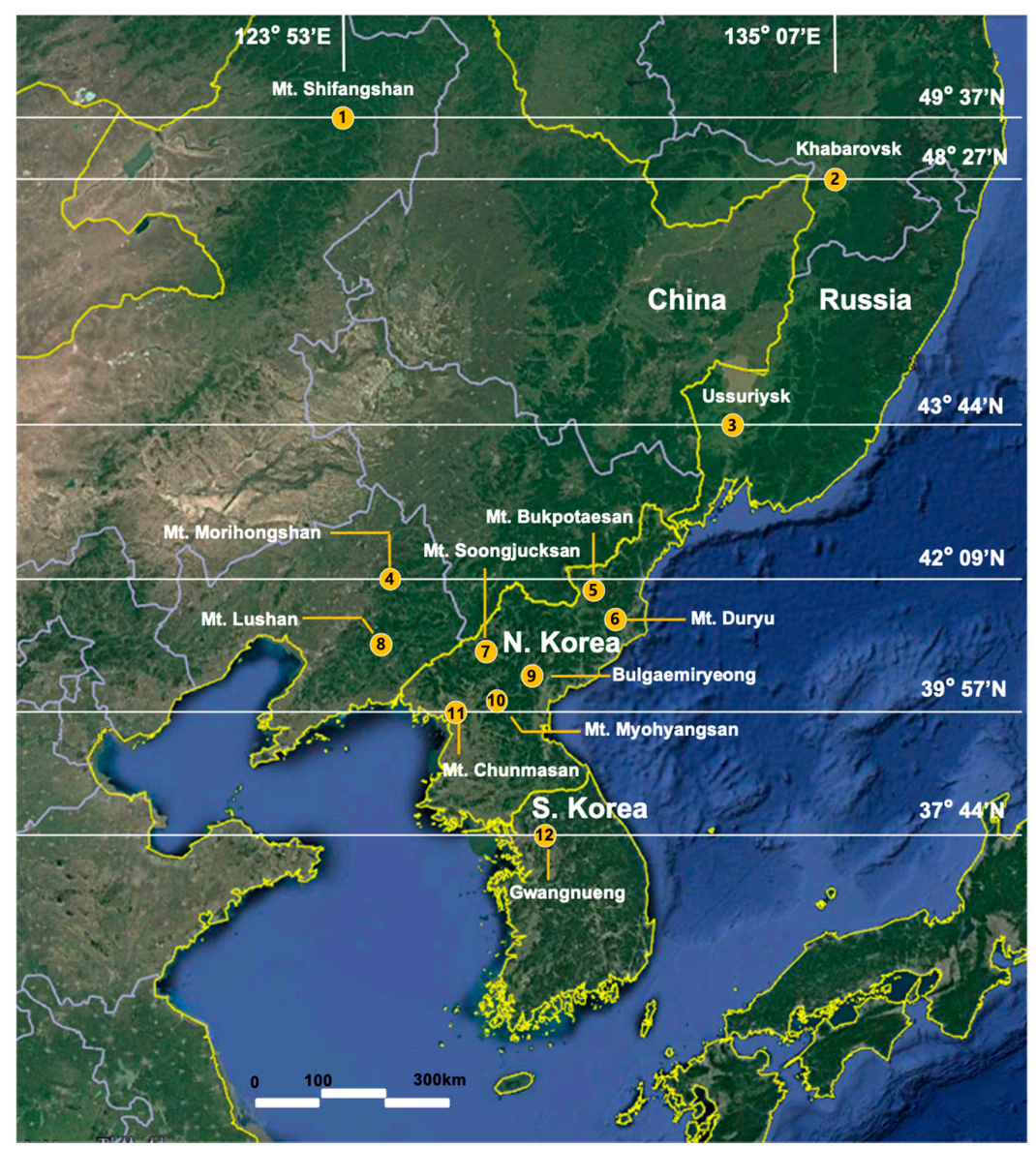

Figure 2. Sampling sites of C. relictus in the present study [11].

While a single adult female was found every year from 2014 to 2017 [18], no female C. relictus was found for almost 20 years in Gwangneung Forest during the period of 1986-2006 [14], and it was not until 2015 that another female was observed [18]. These observations might indicate that the population size in the remaining habitat in South Korea is extremely small. Although the population in Gwangneung Forest is not extinct and its new location is continuously reported, the risk of local extinction in South Korea still remains high $[17,18]$. Conservation of C. relictus, therefore, has emerged as a critical need and it requires restoration of this species in Korea. Restoration practices, such as reintroduction, are becoming an effective and increasingly common strategy for conservation efforts, especially in the cases of dramatically decreasing populations in nature reserves $[19,20]$. For restoration of $C$. relictus, use of the current population in Gwangneung Forest is conceivable, given their continuous occurrences [18]. In some cases, however, reintroduction or translocation may be the only option when the extirpation of endangered populations is imminent [21]. Nevertheless, reintroductions of invertebrates have rarely been performed on local or global scales [21,22]. The vast majority of the reintroduction projects have dealt with vertebrate faunas, whereas only $3 \%$ have dealt with invertebrates [23]. Reintroduction or translocation have been performed for several endangered insect species of Orthoptera, Odonata, Lepidoptera, and Coleoptera all over the world (see Table S1) [20-22,24-37]. In fact, reintroduction or translocation of endangered insect species within a specific domestic region may be a relatively modest task as long as a potential release site has a decent habitat quality [38]. However, in order to introduce locally extinct species from overseas, conservation biologists should overcome biotic and abiotic problems, including genetic diversity, quarantines, parasites, and international legislation and regulation [39-44].

Genetic information, such as the genetic diversity level and phylogeographic history/structure of an endangered species, will assist in developing their effective con- 
servation strategies [45,46]. It can be used for defining evolutionarily significant units or conservation units [47] to preserve the total diversity of endangered populations or species [48].

Furthermore, the level of intraspecific genetic variation has also been suggested to be the population's capacity to adapt to novel environmental conditions [49-51]. In particular, small and isolated populations tend to be vulnerable to stochastic events such as depleted genetic diversity as a consequence of random genetic drift, which facilitates inbreeding depression and thereby local extinction [52]. Reintroduction or restoration for endangered populations unavoidably involves small numbers of individuals as founders. Restoration of the Asiatic black bear (Ursus thibetanus) in South Korea, which is one of the most successful cases for restoration of wild mammals, showed an originally low genetic diversity and the genetic admixture of two source populations, Russia and North Korea, in the restored population based on a combined analysis of mitochondrial and microsatellite markers [53]. Thus, the initial level of genetic diversity of source populations or individuals needs to be carefully considered for successful restoration practices. Understanding the phylogenetic relationships among source populations may be important for successful reintroduction [21]. However, genetic information on the populations of $C$. relictus from different distributions is not available and phylogeographic pattern has not been investigated, despite its unique distribution and conservation value.

Here, we first investigated the level of genetic diversity and divergence of $C$. relictus from the localities covering the whole distribution using two mitochondrial gene sequences, cytochrome oxidase I and II (COI and COII). We aimed to (1) test whether historical gene flow occurred among the current fragmented C. relictus populations in Northeast Asia and (2) to establish a knowledge base of the genetic diversity level and phylogeographic patterns amongst the geographic populations of $C$. relictus in Northeast Asia, in order to provide fundamental information on source populations for developing appropriate conservation strategies, including future restoration and reintroduction programs for this endangered insect species.

\section{Materials and Methods}

\subsection{Sampling and Specimens}

Thirty-two C. relictus specimens from Russia ( $n=8$, from sites 2 and 3), China ( $n=7$, from sites 1, 4, and 8), and North Korea ( $n=17$, from the sites 5, 6, 7, 9, 10, and 11) were collected between 2008 and 2015 (Table 1), preserved in 95\% ethanol, and kept in Yeongwol Insect Museum, Yeongwol, South Korea. Sequences of COI and COII (JN093124 and MF521835, respectively) of C. relictus of South Korean origin available on NCBI GenBank database $[54,55]$ were included, and three Callipogon species (C. barbatum, C. lemoinei, and $C$. senex) from Mexico were used as outgroup species. The collection locations for the sampled specimens are shown in Figure 2 and Table 1.

\subsection{DNA Extraction, Polymerase Chain Reaction (PCR) Amplification, and Sequencing}

Total genomic DNA was isolated from the legs of specimens using DNeasy Blood and Tissue Kit (Qiagen, Germantown, MD, USA), and PCR was performed to amplify fragments of mitochondrial COI (788 bp fragment) and COII (700 bp). PCR was performed with a total reaction volume of $20 \mu \mathrm{L}$ using forward (C1-J-2183: 5'-CAACATTTATTTTGATTTTTTGG$3^{\prime}$ ) and reverse (TL2-N-3014: $5^{\prime}$-TCCAATGCACTAATCTGCCATATTA-3') primers for COI and forward (TL2-J-3043: 5'-TGGCAGATTAGTGCAATGGATTTAA-3') and reverse (TK-N3768: 5'-ACTTGCTTTCAGTCATCTAATG-3') primers for COII modified from published primers [56], using AccuPower PCR Premix (Bioneer, Seoul, Korea) with the following conditions: an initial denaturation at $94{ }^{\circ} \mathrm{C}$ for $1 \mathrm{~min}, 35$ cycles of $30 \mathrm{~s}$ at $94{ }^{\circ} \mathrm{C}, 30 \mathrm{~s}$ at $50-52{ }^{\circ} \mathrm{C}$, and $1-2 \mathrm{~min}$ at $72{ }^{\circ} \mathrm{C}$, and a final extension step at $72{ }^{\circ} \mathrm{C}$ for $7 \mathrm{~min}$. The PCR products were visualized on $1.5 \%$ agarose gel using UV light, purified enzymatically using Exonuclease I and Shrimp Alkaline Phosphatase (New England BioLabs, Ipswich, MA, USA), and sequenced by Macrogen INC Sequencing (Korea) using an ABI PRISM 3130xl 
Genetic Analyzer (Applied Biosystems, Foster city, CA, USA). Sequences of COI and COII of $C$. relictus obtained in the current study were deposited in GenBank under accession numbers MW173845-MW173876 and MW160689-MW160705, respectively. Sequences of COI for Callipogon barbatum, C. senex and C. lemoinei were also deposited under the accession numbers MW173877-MW173879, respectively.

Table 1. Collection and voucher information, and genetic indices of C. relictus samples used for DNA analysis (see Figure 2). Significant values $(p<0.05)$ are indicated in bold.

\begin{tabular}{|c|c|c|c|c|c|c|c|c|c|c|}
\hline Site & Locality (Abbreviation) & GPS & Region & Specimen & $n$ & NH & $h(\mathrm{SD})$ & $\pi(\mathrm{SD})$ & Tajima's $D$ & Fu's $F s$ \\
\hline 1 & $\begin{array}{l}\text { Mt. Shifangshan, } \\
\text { Inner Mongolia, } \\
\text { China (CHSF) }\end{array}$ & $49^{\circ} 37^{\prime} \mathrm{N} / 123^{\circ} 53^{\prime} \mathrm{E}$ & $\begin{array}{l}\text { Northwest } \\
\text { (NW) }\end{array}$ & $\begin{array}{l}\text { CPD-026 } \\
\text { CPD-027 }\end{array}$ & 2 & 2 & $\begin{array}{l}1.000 \\
(0.500)\end{array}$ & $\begin{array}{c}0.013 \\
(0.014)\end{array}$ & 0 & 2.303 \\
\hline 2 & $\begin{array}{l}\text { Khabarovsk Region, } \\
\text { Russia (RUKB) }\end{array}$ & $48^{\circ} 27^{\prime} \mathrm{N} / 135^{\circ} 05^{\prime} \mathrm{E}$ & $\begin{array}{l}\text { Northeast } \\
\text { (NE) }\end{array}$ & CPD-196 & 1 & 1 & $\begin{array}{c}1.000 \\
(0.000)\end{array}$ & $\begin{array}{c}0.000 \\
(0.000)\end{array}$ & 0 & 0 \\
\hline 3 & $\begin{array}{c}\text { Ussuriysk, Primoskij } \\
\text { Kra, } \\
\text { Russia (RUPR) }\end{array}$ & $43^{\circ} 44^{\prime} \mathrm{N} / 131^{\circ} 56^{\prime} \mathrm{E}$ & $\begin{array}{l}\text { Central } \\
\text { North } \\
(\mathrm{CN})\end{array}$ & $\begin{array}{l}\text { CPD-003 } \\
\text { CPD-004 } \\
\text { CPD-189 } \\
\text { CPD-190 } \\
\text { CPD-191 } \\
\text { CPD-197 } \\
\text { CPD-198 }\end{array}$ & 7 & 7 & $\begin{array}{l}1.000 \\
(0.000)\end{array}$ & $\begin{array}{c}0.020 \\
(0.076)\end{array}$ & 1.586 & -0.9891 \\
\hline 4 & $\begin{array}{l}\text { Mt. Morihongshan, } \\
\text { Fushun, Liaoning, China } \\
\text { (CHMR) }\end{array}$ & $41^{\circ} 47^{\prime} \mathrm{N} / 123^{\circ} 58^{\prime} \mathrm{E}$ & $\begin{array}{l}\text { Central } \\
\text { (C) }\end{array}$ & $\begin{array}{l}\text { CPD-180 } \\
\text { CPD-181 } \\
\text { CPD-034 } \\
\text { CPD-035 }\end{array}$ & 4 & 4 & $\begin{array}{c}1.000 \\
(0.177)\end{array}$ & $\begin{array}{c}0.025 \\
(0.017)\end{array}$ & -0.522 & 1.096 \\
\hline 5 & $\begin{array}{l}\text { Mt. Bukpotaesan, } \\
\text { Ryanggang-do, } \\
\text { North Korea (NKBT) }\end{array}$ & $41^{\circ} 41^{\prime} \mathrm{N} / 128^{\circ} 18^{\prime} \mathrm{E}$ & $\begin{array}{l}\text { Central } \\
\text { (C) }\end{array}$ & $\begin{array}{l}\text { CPD-161 } \\
\text { CPD-162 } \\
\text { CPD-163 } \\
\text { CPD-164 }\end{array}$ & 4 & 2 & $\begin{array}{c}0.667 \\
(0.204)\end{array}$ & $\begin{array}{c}0.002 \\
(0.002)\end{array}$ & 1.633 & 1.530 \\
\hline 6 & $\begin{array}{c}\text { Mt. Duryusan, } \\
\text { Hamgyeongnam-do, } \\
\text { North Korea (NKDR) }\end{array}$ & $41^{\circ} 08^{\prime} \mathrm{N} / 128^{\circ} 07^{\prime} \mathrm{E}$ & $\begin{array}{l}\text { Central } \\
\text { (C) }\end{array}$ & $\begin{array}{l}\text { CPD-007 } \\
\text { CPD-010 }\end{array}$ & 2 & 1 & $\begin{array}{c}0.000 \\
(0.000)\end{array}$ & $\begin{array}{c}0.000 \\
(0.000)\end{array}$ & 0 & 0 \\
\hline 7 & $\begin{array}{l}\text { Mt. Soongjucksan, } \\
\text { Jagang-do, North Korea } \\
\text { (NKSJ) }\end{array}$ & $40^{\circ} 27^{\prime} \mathrm{N} / 126^{\circ} 23^{\prime} \mathrm{E}$ & $\begin{array}{l}\text { Central } \\
\text { (C) }\end{array}$ & $\begin{array}{l}\text { CPD-013 } \\
\text { CPD-015 }\end{array}$ & 2 & 2 & $\begin{array}{l}1.000 \\
(0.500)\end{array}$ & $\begin{array}{c}0.007 \\
(0.007)\end{array}$ & 0 & 1.609 \\
\hline 8 & $\begin{array}{l}\text { Mt. Lushan, Beining } \\
\text { West, Liaonin, China } \\
\text { (CHLS) }\end{array}$ & $41^{\circ} 36^{\prime} \mathrm{N} / 121^{\circ} 42^{\prime} \mathrm{E}$ & $\begin{array}{l}\text { Central } \\
\text { (C) }\end{array}$ & CPD-028 & 1 & 1 & $\begin{array}{l}1.000 \\
(0.000)\end{array}$ & $\begin{array}{l}0.000 \\
(0.000)\end{array}$ & 0 & 0 \\
\hline 9 & $\begin{array}{l}\text { Bulgaemiryeong, } \\
\text { Hamgyeongnam-do, } \\
\text { North Korea (NKBG) }\end{array}$ & $40^{\circ} 08^{\prime} \mathrm{N} / 127^{\circ} 53^{\prime} \mathrm{E}$ & $\begin{array}{l}\text { Central } \\
\text { (C) }\end{array}$ & $\begin{array}{l}\text { CPD-016 } \\
\text { CPD-018 } \\
\text { CPD-020 } \\
\text { CPD-022 }\end{array}$ & 4 & 2 & $\begin{array}{c}0.667 \\
(0.204)\end{array}$ & $\begin{array}{c}0.002 \\
(0.002)\end{array}$ & 1.893 & 1.530 \\
\hline 10 & $\begin{array}{l}\text { Mt. Myohyangsan, } \\
\text { Pyeonganbuck-do, } \\
\text { North Korea (NKMH) }\end{array}$ & $39^{\circ} 57^{\prime} \mathrm{N} / 126^{\circ} 16^{\prime} \mathrm{E}$ & $\begin{array}{l}\text { Central } \\
\text { (C) }\end{array}$ & CPD-011 & 1 & 1 & $\begin{array}{l}1.000 \\
(0.000)\end{array}$ & $\begin{array}{c}0.000 \\
(0.000)\end{array}$ & 0 & 0 \\
\hline 11 & $\begin{array}{l}\text { Mt. Chunmasan, } \\
\text { Pyeonganbuk-do, } \\
\text { North Korea (NKCM) }\end{array}$ & $40^{\circ} 00^{\prime} \mathrm{N} / 124^{\circ} 56^{\prime} \mathrm{E}$ & $\begin{array}{l}\text { Central } \\
\text { (C) }\end{array}$ & $\begin{array}{l}\text { CPD-144 } \\
\text { CPD-145 } \\
\text { CPD-146 } \\
\text { CPD-147 }\end{array}$ & 4 & 4 & $\begin{array}{l}1.000 \\
(0.000)\end{array}$ & $\begin{array}{c}0.024 \\
(0.016)\end{array}$ & -0.683 & 1.029 \\
\hline 12 & $\begin{array}{l}\text { Gwangneung Forest } \\
\text { South Korea }\end{array}$ & $37^{\circ} 44^{\prime} \mathrm{N} / 127^{\circ} 09^{\prime} \mathrm{E}$ & South (S) & $\begin{array}{l}\text { JN093124 } \\
(\text { COI }) \\
\text { MF521835 } \\
(\text { COII })\end{array}$ & 1 & 1 & $\begin{array}{l}1.000 \\
(0.000)\end{array}$ & $\begin{array}{c}0.000 \\
(0.000)\end{array}$ & 0 & 0 \\
\hline & $\operatorname{Mexico~(C.~barbartum)~}$ & & & CPD102 & & & & & & \\
\hline & $\begin{array}{l}\text { Mexico (C. senex) } \\
\text { (Outgroup) }\end{array}$ & & & CPD103 & & & & & & \\
\hline & $\begin{array}{l}\text { Mexico (C. lemoinei) } \\
\text { (Outgroup) }\end{array}$ & & & CPD104 & & & & & & \\
\hline
\end{tabular}




\subsection{Phylogenetic Analysis, Genetic Diversity, and Haplotype Network}

A total of 36 sequence reads of COI (788 bp) of C. relictus $(n=33)$ and the three outgroup species (C. barbatum, C. lemoinei, and C. senex) were aligned using Clustal W implemented BioEdit v.7.0.1 [57] and manually edited. Genetic indices (i.e., genetic diversity values) were calculated and Tajima's $D$ and Fu's $F$ s statistics estimated to test for neutrality using MEGA 4.0 [58] and ARLEQUIN v3.5 [59].

Bayesian inference (BI), maximum likelihood (ML), and neighbor-joining (NJ) analyses were conducted for phylogenetic reconstruction. BI and ML trees were inferred for all obtained sequences using MrBayes 3.2 [60] and PhyML v.3.0 [61], respectively. The NJ analysis was conducted using MEGA 4.0. The GTR $+\mathrm{I}+\mathrm{G}$ model was selected as the best fit model for the BI and ML analyses using initial searches, according to the Akaike information criterion (AICc) with jModelTest v2.1.7 [62]. The BI analysis was conducted for 10 million generations, sampling every 100 , and the first $25 \%$ were discarded as burn-in. The average standard deviation values of split frequencies for both runs were less than 0.01 , indicating that the concurrent runs converged. The potential scale reduction factor (PSRF) of 1.0 verified the reliability of samples from the posterior probability distribution. Statistical support for both the ML and NJ analyses was obtained using 1000 bootstrap pseudo-replicates. $\mathrm{NJ}$ analysis was only performed for COII gene due to very low levels of overall intraspecific mean diversity (0.004) of C. relictus $(n=17)$.

The haplotypes of the 33 individuals of C. relictus were determined using NJ algorithms in DnaSP v5 [63]. The genetic diversity indices including haplotype diversity $(h)$ and nucleotide diversity $(\pi)$ were estimated using ARLEQUIN v3.5. A haplotype network was inferred using HAPSTAR v0.7 [64].

\subsection{Geographic Population Structure}

Spatial population genetic structure of $C$. relictus was accessed by a hierarchical analysis of molecular variance (AMOVA) analysis, implemented in ARLEQUIN v3.5. Each of the 12 populations (Table 1) was assigned to one of five geographical regions, i.e., Northeast (NE), Northwest (NW), Central North (CN), Central (C), and South (S). The populations were assigned into two groups according to the latitudinal degree. First groupings were separated into upper and lower regions from the latitude $40^{\circ} 00^{\prime} \mathrm{N}$ and second groupings were separated by the latitude $43^{\circ} 00^{\prime} \mathrm{N}$. Total molecular variance was partitioned among groups ( $\mathrm{Fct}=$ 'inter-group' genetic variation), populations within groups ( $\mathrm{Fsc}=$ 'intra-group' genetic variation), and populations regardless of groupings ( $\mathrm{Fst}=$ 'inter-population').

\section{Results}

\subsection{Genetic Diversity and Phylogenetic Analyses}

A total of 17.0 and $23.7 \%$ of the sites in the $C O I$ alignment were variable and parsimony informative, respectively. The average genetic divergence, based on Kimura-2-parameter distance estimation, was 0.022 (ranging from 0 to 0.047 ) among the $C$. relictus specimens, but 0.049 (ranging from 0 to 0.219 ) among C. barbatum, C. lemoinei, and C. senex (Table S2). All C. relictus specimens from the 12 localities formed a well-supported monophyly, with high posterior probability (100) and bootstrap (100) values (Figure 3). Two internal clades were identified and mean distance between two clades (Clades I and II) was 0.038 , with a range of 0.014 to 0.046 . Mean distances within each clade were 0.005 and 0.007 for clades I and II, respectively, indicating that the genetic divergence of the geographically distant $C$. relictus individuals in each clade is low (Figure 3). Despite forming two distinct clades in all analyses (BI, ML, and NJ), no geographical clusters based on the localities were identified (Figures 3 and 4). Furthermore, one specimen from South Korea (JN093124) was clustered with specimens from North Korea (DR, BG, MH: specimen identifier, Figure 3) and China (LS, MR) with high supporting values (94-100). Populations of the Shifangshan locality (Inner Mongolia, China; site 1) were genetically closer to the population of the geographically distant ( $>1400 \mathrm{~km}$ ) Gwangneung locality (South Korea; site 12) than to populations of the much closer (900-1300 km) Russian localities (KB, PR; site 3). Populations of the 
North Korean localities (CM, BT, SJ, DR, BG; Central region) exhibited the greatest genetic diversity and were genetically equidistant to the South Korean population (JN093124).

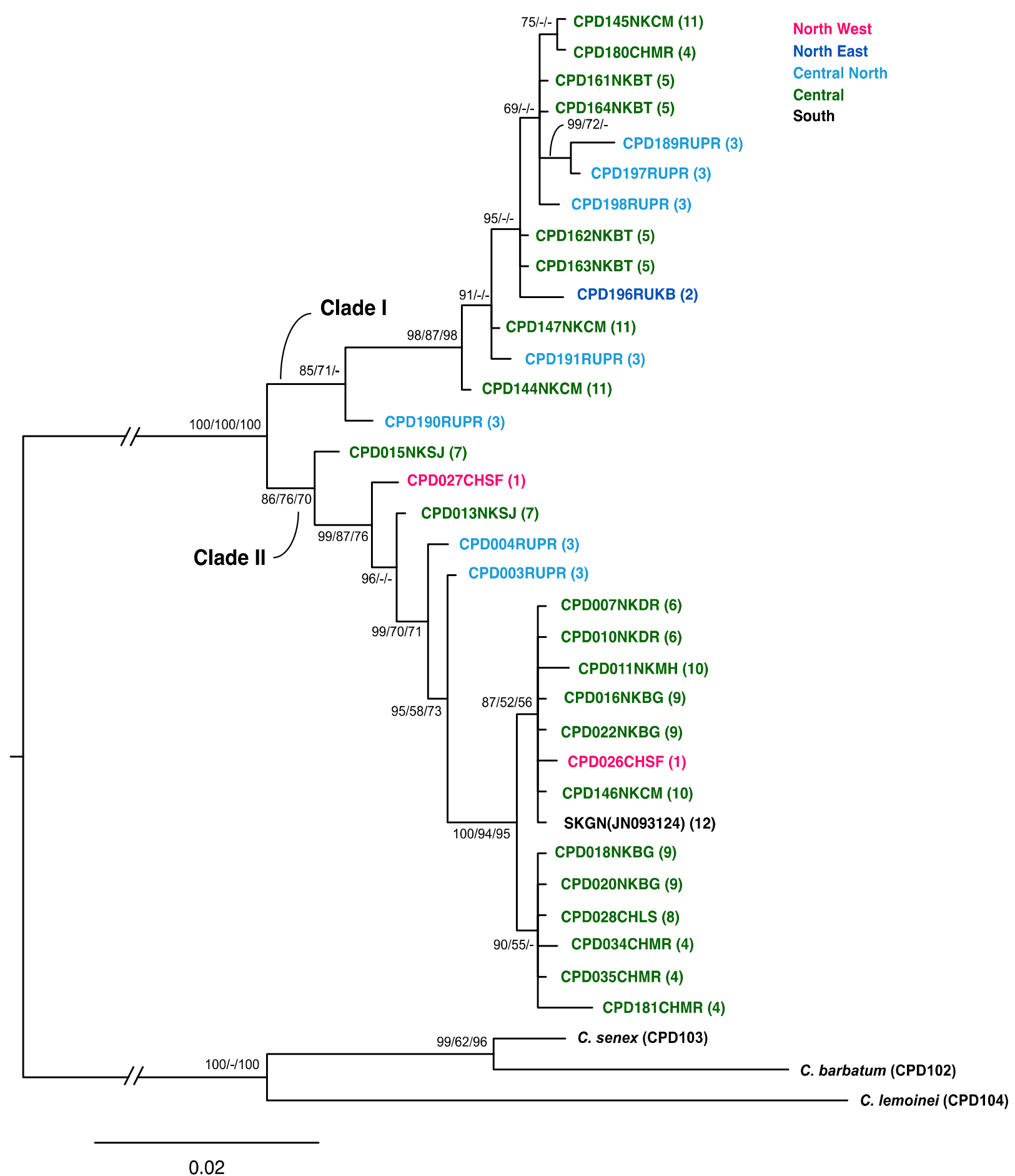

Figure 3. Phylogenetic tree of C. relictus using COI sequences and tree topology is shown based on Bayesian inference. Sampling site numbers are shown in the parentheses. The numbers above the nodes indicate Bayesian posterior probabilities (BI), maximum likelihood (ML), and neighbor-joining (NJ) bootstrap values, respectively. The nodes with values $<50 \%$ are shown as "-".

A total of 17 COII gene sequences (700 bp each) of C. relictus had only five parsimonious informative sites $(0.7 \%)$, the genetic distance between pairwise comparisons of all the sequences based the Kimura-2-parameter model ranged from 0 to 0.012 , and the overall average distance was 0.004 (Table S3). Therefore, the COII gene phylogenetic tree could 
not provide enough resolution for the phylogenetic inference, as a result of a very low level of divergence within species and among individuals from different regions, including Russia and China (Figure S1). Based on our results of COI and COII genes, we inferred that $C$. relictus specimens from Russia, China, North Korea, and South Korea might belong to a single species with identical monophyletic clustering. No distinct phylogeographic structures were detected (Figures 3 and 4). However, two well-separated genetic clades of moderate levels of divergence (3.8\%) in the COI phylogeny might indicate these may represent cryptic species diversity in $C$. relictus.

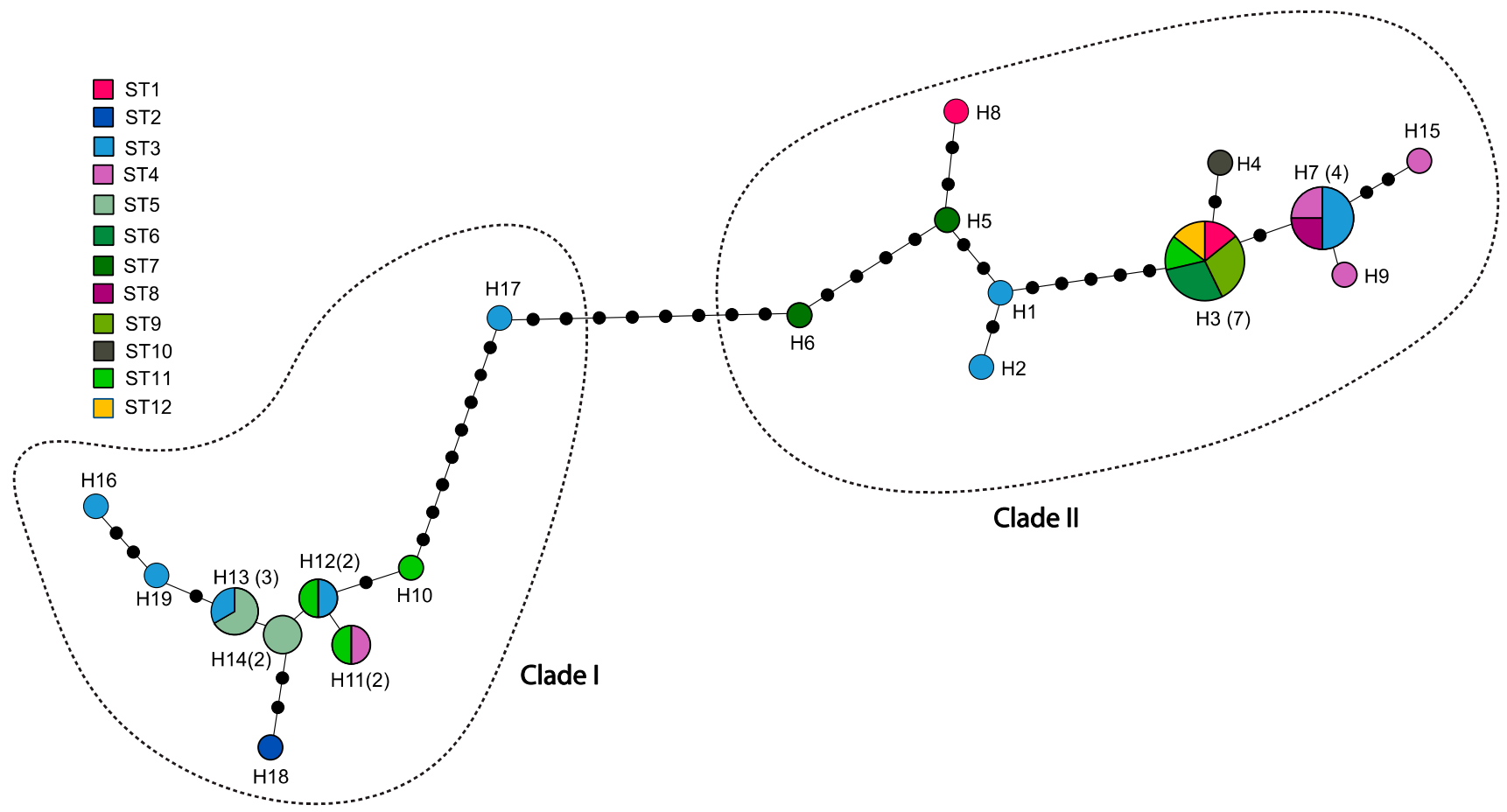

Figure 4. Haplotype network of COI sequences from C. relictus specimens from 12 localities. Each line represents a single mutational step, irrespective of length. Individual numbers of the respective haplotypes are presented in parentheses unless it was one individual.

\subsection{Haplotype Analysis}

A total of 19 haplotypes of COI genes of specimens from the 12 localities (Figure 4) were obtained with a haplotype diversity $(h)$ of 0.9375 . The number of unique haplotypes (singletons) obtained from single individuals was $13(39 \%)$, and the most common haplotype $(\mathrm{H} 3, n=7)$ was shared among North Korea $(n=5)$, China $(n=1)$, and South Korea $(n=1)$. A linear pattern of haplotype network was identified, and haplotypes, shared by more than two individuals, were located at both marginal ends of the network rather than being in the middle.

\subsection{Geographical Population Structure and Demographic History}

AMOVA could not detect any significant genetic structures between two groups when the 12 populations were divided by the latitudinal degree of $40^{\circ} 00^{\prime} \mathrm{N}$ (I) or $43^{\circ} 00^{\prime} \mathrm{N}$ (II) (Table 2). Molecular variances for both groupings (I and II) were $-7.53\left(\varphi_{C T}=-0.075\right)$ and $-25.85 \%\left(\varphi_{C T}=-0.259\right)$, respectively. Most of the variances were observed among populations within groups and within populations in both biogeographical groupings (Table 2). Non-significant genetic structure between two groups would indicate that the historical gene flow occurred among C. relictus populations in Northeast Asia. All of the 12 populations were pooled as a single data set, with Tajima's $D$ and Fu's Fs values of $-0.83410(p=0.168)$ and $1.23247(p=0.707)$, respectively. 
Table 2. Analysis of molecular variance (AMOVA) of C. relictus in Northeast Asia. Significant $p$-values $(p<0.05)$ are indicated in bold.

\begin{tabular}{|c|c|c|c|c|c|c|}
\hline Grouping & Source of Variation & d.f. & $\begin{array}{l}\text { Sum of } \\
\text { Squares }\end{array}$ & $\begin{array}{c}\text { Variance } \\
\text { Components }\end{array}$ & $\begin{array}{l}\text { Percentage of } \\
\text { Variation }\end{array}$ & $\phi$-Statistics \\
\hline \multirow{3}{*}{$\begin{array}{l}2 \text { groups (I) } \\
\text { (Upper vs. lower } \\
\text { from the latitude } \\
40^{\circ} 00^{\prime} \mathrm{N} \text { ) }\end{array}$} & Among groups & 1 & 16.410 & -0.66370 & -7.53 & $\phi_{\mathrm{CT}}=-0.075$ \\
\hline & $\begin{array}{l}\text { Among populations } \\
\text { Within groups }\end{array}$ & 10 & 155.610 & 4.24547 & 48.19 & $\phi_{\mathrm{SC}}=\mathbf{0 . 4 4 8}$ \\
\hline & Within populations & 212 & 109.786 & 5.22789 & 59.34 & $\phi_{\mathrm{ST}}=\mathbf{0 . 4 0 7}$ \\
\hline \multirow{3}{*}{$\begin{array}{l}2 \text { groups (II) } \\
\text { (Upper vs. lower } \\
\text { from the latitude } \\
43^{\circ} 00^{\prime} \mathrm{N} \text { ) }\end{array}$} & Among groups & 1 & 2.679 & -1.95599 & -25.85 & $\phi_{\mathrm{CT}}=-0.259$ \\
\hline & $\begin{array}{l}\text { Among populations } \\
\text { Within groups }\end{array}$ & 10 & 169.081 & 4.29419 & 56.76 & $\phi_{\mathrm{SC}}=\mathbf{0 . 4 5 1}$ \\
\hline & Within populations & 21 & 109.786 & 5.22789 & 69.10 & $\phi_{\mathrm{ST}}=\mathbf{0 . 3 0 9}$ \\
\hline
\end{tabular}

Significant $p$-values $(p<0.05)$ are indicated in bold.

\section{Discussion}

We first document the phylogeographic patterns of Callipogon relictus remnant populations in Northeast Asia to provide baseline information for developing effective conservation or restoration strategies. Callipogon relictus specimens from the 12 different geographical locations, which cover almost the whole distribution of the species and extend across a distance of $\sim 1400 \mathrm{~km}$ from the northern (Mt. Shifangshan, Inner Mongolia) to the southern limit (Gwangneung Forest in South Korea), did not show any distinct geographical structures (Figures 2-4, Figure S1, and Table 2). We found that several of the specimens collected in Russia were more similar to those from China or even South Korea than to others from Russia (Figures 3 and 4). This genetic similarity among distantly located specimens (700-800 km) and no genetic structures between two groupings by the latitudinal degree (Table 2) might explain the unique origins and evolutionary history of the species. Callipogon relictus has been known to have a very limited dispersal ability, as its large body size greatly impedes flight capacity [10]. In fact, individuals hardly fly and move only a few hundred meters during their 1-2-month-long adult life [10]. Therefore, gene flow by dispersal between distantly located populations (i.e., northern Russian Far East and South Korea) is unlikely, although precise estimation of direct flight ability has not been tested. Since an ongoing gene flow is unlikely owing to the poor dispersal mobility of C. relictus, the lack of genetic structure among populations and the linear pattern of the haplotype network with numerous mutational steps between haplotypes (Figure 4) might indicate that the current fragmented populations of $C$. relictus are remnants of genetically largely diverse ancestral populations in the past (Figure 4). Furthermore, haplotype diversity $(h)$ (i.e., 0.9357 ) with $39 \%$ of singletons of $C$. relictus from 12 localities is much higher than other threatened saproxylic beetles. For examples, Rosalia alpina, an endangered and strictly protected saproxylic beetle, showed 0.541 of haplotype diversity from Central and South-East Europe [65] and 0.687 of haplotype diversity from the expanded regions, including a Russian population [66]. On the contrary, high levels of haplotype diversity were often identified in emerging pest species of longhorn beetles. For example, emerging or population-expanded pest species such as Monochamus sartor, which is one of the famous timber pests [67], Rhagium inquisitor, a ribbed-pine borer [68], and Massicus raddei [69], a serious trunk borer, showed relatively high haplotype diversity of 1.0, 0.708, and 0.96, respectively. Although a high level of genetic diversity generally indicates a large effective population size [70], the high risk of population size decreases or local extinction was reported in this species in known distributions [6,7,14,18]. This higher haplotype diversity, given the actual size of local populations, might further support the idea that a genetically diverse population of $C$. relictus existed before and fragmented into its present distributions.

Two distinct clades in the COI phylogeny from 12 different localities could support the hypothesis that the current regional populations of C. relictus that we analyzed might represent the remnants of ancestral populations with genetic mosaics. Although average genetic distance was $2.2 \%$ among all 33 individuals from 12 different sites, a much greater 
distance was found between several individuals belonging to the two different clades (Clade I, II; Figure 3). For example, 3.8\% of genetic divergence, which was beyond the generally known intra-specific divergence level (i.e., $<2-3 \%$ ) in insects [71], was identified even from individuals in the same localities. In general, $>2-3 \%$ sequence divergences have been suggested to be appropriate for delineating species boundaries in animal taxa [71], despite it surely being taxon-specific. Alternatively, two genetic forms or possibly subspecies relationships from two distinct clades are plausible (Figure 3). The haplotype network also showed that haplotypes belonging to two clades also were separated with a large number of mutational steps (Figure 4). However, individuals belonging to two distinct clades were not morphologically differentiated and geographical structures were not identified either. High intra-specific divergence of more than $4 \%$ was often observed in longhorn beetles (e.g., $>6 \%$ in Parechthistatus gibber) [72]. Thus, two distinct clades with high genetic divergence between several individuals could be interpreted as evidence supporting the notion that a genetically diverse population of $C$. relictus existed before and fragmented into its present distributions. However, we should note that the level of genetic diversity and phylogeographic pattern could be over- or underestimated due to the small sample size and geographical gaps of sampling sites in this study, since physical access to local populations and achieving large sample sizes for this endangered species are very challenging.

Genetic diversity in the COI gene is known to be a good proxy for the evaluation of the conservation status of the species in the case of a lack of previous information and census data [73]. Knowledge of the level of genetic variations and conservation status is also essential to establish a conservation plan for endangered populations, even if the sample size is smaller than ideal [74]. Although we used only a single phylogeographic marker (mtDNA COI) for this study, our data enable to uncover the levels of genetic diversity, divergence among populations, and also phylogeographic history of $C$. relictus. We are currently developing novel nuclear microsatellite markers, which can be further used for more detailed conservation study. The results of our phylogenetic and haplotype analyses could suggest that all the $C$. relictus sites surveyed in the present study could be used as a source population of $C$. relictus to the sites which are facing dramatic population decrease, as all the local populations constitute a monophyletic group with an intraspecific level of genetic divergence. For example, such reintroduction would likely improve the genetics of C. relictus in South Korea cases by increasing the genetic diversity of the local population via outbreeding. The present study indicates that the South Korean group exhibits the highest genetic similarity, compared to the North Korean (Central), Chinese (North West), and Russian (Central North) groups, in this order (Figures 3 and 4, and Table 1). Such genetic similarity further highlights the value of the Russian and North Korean populations for conservation of this species, with a relatively large population size, in the part of the historical range where local extinction is imminent. Alternatively, if the current population in Gwangneung forest in South Korea is used for an effective conservation strategy to preserve the genetic and ecological attributes of the Korean population, which is located in the species' southern limit (Figure 2), the level of genetic divergence can be a standard for long-term monitoring of the restored population. In both cases, the knowledge of the genetic diversity and phylogeographic pattern of $C$. relictus populations covering major geographic distributions examined in the present study would be valuable for preserving current local populations and designing the successful development of a conservation program for this endangered longhorn beetle species.

If the pattern of the current C. relictus population is a consequence of fragmentation from the genetically fairly varied populations in the past, the reasons behind the severe reduction in populations in South Korea, in contrast to those in Russia, should be more thoroughly studied for a successful conservation program. Dramatic decreases in the Korean peninsula population have been suggested to stem from global climate change [14]. Indeed, as $C$. relictus was found to have a limited distribution with a southernmost limit above $37^{\circ} \mathrm{N}$, it may be hypothesized that the distributional range of $C$. relictus is associated with 
higher latitudes. The influence of temperature and global change on the abundance and distribution of terrestrial invertebrates are well-documented in most Lepidoptera [75-80] and Orthoptera [78]. However, saproxylic beetles, which are wood-boring internal feeders like most cerambycid beetles, may be less sensitive to climate change and increasing temperature than external feeders, and may even thrive under such conditions. Therefore, increased temperature could accelerate larval development [81,82], reduce the duration of diapause $[83,84]$, and may increase the number of generations per year of multivoltine insects $[81,85]$. Moreover, even summer drought associated with high temperature can cause large-scale beetle outbreaks on weakened and dead host trees $[85,86]$. It was also reported that the ancestors of $C$. relictus were not northern or boreal species but rather adapted to the climate of Northeast Asia [4]. Recently, experimental evidence that higher temperatures both accelerate larval development and increase body size was reported [82,87]. An alternative hypothesis for the local extinction or dramatic population decreases of $C$. relictus in South Korea is that the rapid reduction in population was caused by anthropogenic habitat destruction rather than climate change. It is also worth noting that the systematic logging of Caprinus laxiflora, C. laxiflora, Quercus aliena, and Q. serrata [18], which is the principal host of C. relictus, in the Gwangneung Forest during the 1970s resulted in a temporal shortage of suitable host trees and dramatically reduced the Gwangneung population, which is located at the southern limit of the species distribution, in a region that may be a unique habitat in South Korea. It might be concluded that the massive logging of C. laxiflora colonies resulted in the simultaneous removal of multiple generations of juveniles developing in the timbers.

The information on the genetic diversity and phylogeographic pattern/structure of C. relictus populations, spanning almost its entire geographical range, analyzed in the present study will provide baseline, but valuable guidelines for maintaining current local populations and also for developing a successful conservation program for this endangered longhorn beetle species.

Supplementary Materials: The following are available online at https://www.mdpi.com/article/10 $.3390 /$ insects12060555/s1, Figure S1: Neighbor-joining phylogenetic tree of C. relictus using COII gene. The numbers above the nodes indicate neighbor-joining (NJ) bootstrap values. The nodes with values $>40 \%$ are shown, Table S1: Cases of reintroduction/translocation projects of endangered insect species, Table S2: Pairwise genetic distance matrix of COI among specimens of Callipogon relictus, C. barbartum (CPD102), C. senex (CPD103), and C. lemoinei (CPD104), Table S3: Pairwise genetic distance matrix of COII sequences among specimens of Callipogon relictus and C. barbartum (CPD102).

Author Contributions: Conceptualization, J.H.K., D.-A.Y. and Y.J.B.; methodology, J.H.K. and D.A.Y.; software, J.H.K.; validation, J.H.K. and D.-A.Y.; formal analysis, J.H.K. and D.-A.Y.; investigation, J.H.K., D.-A.Y., A.V.K., C.H. and Y.J.B.; resources, D.-A.Y., A.V.K. and C.H.; data curation; J.H.K. and D.-A.Y.; writing — original draft preparation, J.H.K. and D.-A.Y.; writing—review and editing, J.H.K., D.-A.Y., A.V.K., C.H. and Y.J.B.; visualization, J.H.K. and D.-A.Y.; supervision, Y.J.B.; project administration, J.H.K., D.-A.Y. and Y.J.B.; funding acquisition, J.H.K. and A.V.K. All authors have read and agreed to the published version of the manuscript.

Funding: The study was conducted as part of an international collaborative project for the conservation of Callipogon relictus between the Center for the Study of Insect Ecology, Yeongwol, Korea, and Federal Scientific Center of the East Asia Terrestrial Biodiversity, Far Eastern Branch of the Russian Academy of Sciences, Vladivostok, Russia Federation. J.H.K. was funded by a grant (NRF2017R1C1B1010741, 2020R1C1C1007098) from the Basic Science Research Program, through the National Research Foundation of Korea (NRF), which is funded by the Ministry of Science, ICT, and Future Planning. The work of A.V.K. was funded by the Russian Foundation for Basic Research as per the research project No. 16-34-00323 and was carried out within the framework of the state research task: AAAA-A18-118052590019-7, AAAA-A17-117062710084-7.

Institutional Review Board Statement: Not applicable.

Data Availability Statement: Data are available upon request from the authors. 
Acknowledgments: We acknowledge the support provided from the members of the Research Center of Natural Monument Insects and Federal Scientific Center of the East Asia Terrestrial Biodiversity for acquisition of valuable specimens.

Conflicts of Interest: The authors declare no conflict of interest.

\section{References}

1. Semenov, A.P. Callipogon (Eoxenus) relictus sp. n. new species of Cerambycidae in fauna of Russia. Russ. Entomol. J. 1899, 32, 562-580.

2. Semenov, A.P. Another undescribed male Callipogon (Eoxenus) relictus Sem. (Coleoptera, Cerambycidae). Rus. Entomol. Obozr. 1903, 6, 372-373.

3. Monné, M. Catalogue of the Cerambycidae (Coleoptera) of the Neotropical Region. Part III. Subfamilies Lepturinae, Necydalinae, Parandrinae, Prioninae, Spondylidinae and Families Oxypeltidae, Vesperidae and Disteniidae. Zootaxa 2018, 1212, 1. [CrossRef]

4. Kim, S.I.; De Medeiros, B.A.S.; Byun, B.K.; Lee, S.H.; Kang, J.H.; Lee, B.W.; Farrell, B.D. West meets east: How do rainforest beetles become circum-Pacific? Evolutionary origin of Callipogon relictus and allied species (Cerambycidae: Prioninae) in the New and Old Worlds. Mol. Phylogenet. Evol. 2018, 125, 163-176. [CrossRef] [PubMed]

5. Cho, B.S. On several species of long-horned beetle from Korea peninsular. Mag. Nat. Hist. 1934, $17,41$.

6. Kuprin, A.V.; Bezborodov, V.G. Geographic range of Callipogon relictus Semenov, 1899 (Coleoptera, Cerambycidae) in the Russian Far East. Izv. RAN. Ser. Biol. 2012, 39, 459-463.

7. Kuprin, A.V.; Bezborodov, V.G. Areal of Callipogon relictus Semenov, 1899 (Coleoptera, Cerambycidae) in the Russian Far East. Biol. Bull. 2012, 39, 387-391. [CrossRef]

8. Yi, D.A.; Kuprin, A.V.; Bae, Y.J. Distribution of the longhorned beetle Callipogon relictus (Coleoptera: Cerambycidae) in Northeast Asia. Zootaxa 2018, 4369, 101-108. [CrossRef]

9. Kuprin, A.V.; Bezborodov, V.G.; Yi, D.A.; Kotlyar, A.K. Developmental Biology and Ecological Peculiarities of the Relict Longhorn Beetle Callipogon relictus Semenov, 1899 (Coleoptera, Cerambycidae). Entomol. Rev. 2014, 94, 1251-1256. [CrossRef]

10. Yi, D.A. Breeding and Restoration of Korean Relic Long-Horned Beetle: Callipogon Relictus; National Institute of Biological Resources: Incheon, Korea, 2014.

11. Google. Gwangneung, South Korea. Available online: https://www.google.co.kr/maps/search/Gwangneung/@40.9094805,119. $9757406,6 z ? h \mathrm{l}=$ en (accessed on 22 May 2021).

12. Murayama, J. On the larva and food plant of Callipogon relictus Semenov. Jpn. J. Entomol. 1936, 10, $280-290$.

13. Kim, C.W.; Yoon, I.B.; Nam, S.H. On the habitats and habits of Callipogon relictus. (Coleoptera: Cerambycidae). Nat. Conserv. 1976, 11, 5-16.

14. Byun, B.K.; Kwon, T.S.; Weon, G.J.; Jo, D.G.; Lee, B.W.; Lee, Y.M.; Choi, H.J.; Kim, C.H.; Lee, S.H.; Bae, Y.S.; et al. Occurrence of Callipogon relictus Semenov (Coleoptera: Cerambycidae) in the Gwangneung Forest, Korea with suggestion for the conservation. Korean J. Appl. Entomol. 2007, 46, 19-25. [CrossRef]

15. Li, J.; Drumont, A.; Xueping, G.; Wei, G. The checklist of Northeast China's subfamily Prioninae and biological observations of Callipogon (Eoxenus) relictus Semenov-Tian-Shanskij 1899 (Coleoptera, Cerambycidae, Prioninae). Les Cah. Magellanes 2012, $9,50-56$.

16. Lim, J.; Jung, S.Y.; Lim, J.S.; Jang, J.; Kim, K.M.; Lee, Y.M.; Lee, B.W. A review of host plants of Cerambycidae (Coleoptera: Chrysomeloidea) with new host records for fourteen Cerambycids, including the Asian Longhorn Beetle (Anoplophora glabripennis Motschulsky), in Korea. Korean J. Appl. Entomol. 2014, 53, 111-133. [CrossRef]

17. Lee, S.G.; Kim, C.; Choi, I.J.; Kuprin, A.V.; Lim, J. A review of host plants of Callipogon (Eoxenus) relictus Semenov (Coleoptera: Cerambycidae: Prioninae), a Korea natural monument, with a new host, Quercus aliena Blume. J. Asia Pac. Entomol. 2019, 22, 353-358. [CrossRef]

18. Lee, S.G.; Kim, C.; Kuprin, A.V.; Kang, J.H.; Lee, B.W.; Oh, S.H.; Lim, J. Survey research on the habitation and biological information of Callipogon relictus Semenov in Gwangneung forest, Korea and Ussurisky nature reserve, Russia (Coleoptera, Cerambycidae, Prioninae). ZooKeys 2018, 792, 45-68. [CrossRef] [PubMed]

19. Seddon, P.J.; Armstrong, D.P.; Maloney, R. Developing the science of reintroduction biology. Conserv. Biol. 2007, 21, 303-312. [CrossRef]

20. Dempster, J.P.; Hall, M.L. An attempt at re-establishing the swallowtail butterfly at Wicken Fen. Ecol. Entomol. 1980, 5, 327-334. [CrossRef]

21. Drag, L.; Cizek, L. Successful reintroduction of an endangered veteran tree specialist: Conservation and genetics of the Great Capricorn beetle (Cerambyx cerdo). Conserv. Genet. 2015, 16, 267-276. [CrossRef]

22. Knisley, C.B.; Hill, J.M.; Scherer, A.M. Translocation of threatened tiger beetle Cicindela dorsalis dorsalis (Coleoptera: Cicindelidae) to Sandy Hook, New Jersey. Ann. Entomol. Soc. Am. 2005, 98, 552-557. [CrossRef]

23. Bajomi, B.; Pullin, A.S.; Stewart, G.B.; Takács-Sánta, A. Bias and dispersal in the animal reintroduction literature. Oryx 2010, 44, 358-365. [CrossRef]

24. Cunningham, A.A.; Frank, J.M.; Croft, P.; Clarke, D.; Pearce-Kelly, P. Mortality of captive British wartbiter cricket: Implications for reintroduction programs. J. Wildl. Dis. 1997, 33, 673-676. [CrossRef] 
25. Baur, B.; Thommen, G.H.; Coray, A. Dynamics of reintroduced populations of Oedipoda caerulescens (Orthoptera, Acrididae) over 21 years. J. Insect Sci. 2017, 17, 1-7. [CrossRef] [PubMed]

26. Gardiner, T. Mottled grasshopper translocation to sand dunes in Essex, England. In Global Reintroduction Perspectives; IUCN/SSC Re-introduction Specialist Group \& Environment Agency: Abu Dhabi, United Arab Emirates, 2011.

27. Hannon, E.R.; Hafernik, J.E. Reintroduction of the rare damesfly Ischnura gemina (Odonata: Coenagrionidae) into an urban California park. J. Insect Conserv. 2007, 11, 141-149. [CrossRef]

28. Englund, R.A. The impacts of introduced poeciliid fish and Odonata on endemic Megalagrion (Odonata) damselflies on O'ahu Island, Hawai'i. J. Insect Conserv. 1999, 3, 225-243. [CrossRef]

29. Preston, D.J.; Englund, R.A.; McShane, M.K.K. Translocation and monitoring efforts to establish a second population of one of the rare Megalagrion xanthomelas (Selys-Longchamps) on O'ahu, Hawai'i (Zygoptera: Coenagrionidae). Bish. Mus. Bull. Cult. Environ. Stud. 2007, 3, 261-276.

30. Andersen, A.; Simcox, D.; Thomas, J.A.; Nash, D.R. Assessing reintroduction schemes by comparing genetic diversity of reintroduced and source populations: A case study of the globally threatened large blue butterfly (Maculinea arion). Biol. Conserv. 2014, 175, 34-41. [CrossRef]

31. Wynhoff, I. Lessons from the reintroduction of Maculinea teleius and M. nausithous in the Netherlands. J. Insect Conserv. 1998, 2, 47-57. [CrossRef]

32. Duffey, E. The reestablishment of the large copper butterfly Lycaena dispar batavus Obth. on Woodwalton Fen National Nature Reserve, Cambridgeshire, England, 1969-1973. Biol. Conserv. 1977, 12, 143-158. [CrossRef]

33. Chan, P.K.; Packer, L. Assessment of potential Karner Blue Butterfly (Lycaeides melissa samuelis) (Family: Lycanidae) reintroduction sites in Ontario, Canada. Restor. Ecol. 2006, 14, 645-652. [CrossRef]

34. Babione, M. Bringing tiger beetles together. Endanger. Species Bull. 2003, 28, 28-29.

35. Amaral, M.; Kozo, A.; French, T. Conservation status and reintroduction of the endangered American burying beetle. Northeast. Nat. 1997, 4, 121-132. [CrossRef]

36. Mckenna-Foster, A.; Perrotti, L.; Blyth, J.; LoPresti, E.; Kennedy, R.S. Measuring success of a reintroduced population of the American burying beetle (Nicrophorus americanus Olivier) to Nantucket Island, MA. J. Insect Conserv. 2016, 20, 895-904. [CrossRef]

37. Yoon, T.J.; Park, H.C.; Kang, J.H.; Bayartogtonkh, B.; Bae, Y.J. Genetic divergence between the South Korean and Mongolian populations of the dung beetle, Gymnopleurus mopsus (Coleoptera: Scarabaeidae) based on mitochondrial cytochrome c oxidase subunit I (COI) gene sequences. Entomol. Res. 2017, 47, 366-372. [CrossRef]

38. Armstrong, D.P.; Seddon, P.J. Directions in reintroduction biology. Trends Ecol. Evol. 2008, 23, 20-25. [CrossRef] [PubMed]

39. Lachenmeier, R.R. The Endangered Species Act of 1973: Preservation or Pandemonium. Environ. Law 1974, 5, 29.

40. Pyle, R.M. The Eco-Geographic Basis for Lepidoptera Conservation. Ph.D. Thesis, Yale University, New Haven, CT, USA, 1976.

41. Pyle, R. Insect Conservation. Annu. Rev. Entomol. 1981, 26, 233-258. [CrossRef]

42. Anon. CITES Permits and Certificates; Office of Management Authority, U.S. Fish and Wildlife Service: Washington, DC, USA, 1999.

43. IUCN. Guidelines for Reintroductions and Other Conservation Translocations; Version 1.0; IUCN/SSC Reintroduction Specialist Group: Grand, Switzerland, 2013.

44. Jorgensen, D. Conservation implications of parasite co-reintroduction. Conserv. Biol. 2014, 29, 602-604. [CrossRef]

45. Moritz, C.; Faith, D.P. Comparative phylogeography and the identification of genetically divergent areas for conservation. Mol. Ecol. 1998, 7, 419-429. [CrossRef]

46. Godoy, J.A.; Negro, J.J.; Hiraldo, F.; Donázar, J.A. Phylogeography, genetic structure and diversity in the endangered bearded vulture (Gypaetus barbatus, L.) as revealed by mitochondrial DNA. Mol. Ecol. 2004, 13, 371-390. [CrossRef]

47. Ryder, O.A. Species conservation and systematics: The dilemma of subspecies. Trends Ecol. Evol. 1986, 1, 9-10. [CrossRef]

48. Green, D.M. Designatable units for status assessment of endangered species. Conserv. Biol. 2005, 19, 1813-1820. [CrossRef]

49. Futuyma, D.J.; Peterson, S.C. Genetic variation in the use of resources by insects. Annu. Rev. Entomol. 1985, 30, 217-238. [CrossRef]

50. Robinson, B.W.; Wilson, D.S. Genetic variation and phenotypic plasticity in a trophically polymorphic population of pumpkinseed sunfish (Lepomis gibbosus). Evol. Ecol. 1996, 10, 631-652. [CrossRef]

51. Agashe, D. The stabilizing effect of intraspecific genetic variation on population dynamics in novel and ancestral habitats. Am. Nat. 2009, 174, 255-267. [CrossRef] [PubMed]

52. Geist, J. Strategies for the conservation of endangered freshwater pearl mussels (Margaritifera margaritifera L.): A synthesis of conservation genetics and ecology. Hydrobiologia 2010, 644, 69-88. [CrossRef]

53. Kim, Y.K.; Hong, Y.J.; Min, M.S.; Kim, K.S.; Kim, Y.J.; Voloshina, I.; Myslenkov, A.; Smith, G.J.D.; Cuong, N.D.; Tho, H.H.; et al. Genetic status of Asiatic black bear (Ursus thibetanus) reintroduced into South Korea based on DNA and microsatellite loci analysis. J. Hered. 2011, 102, 165-174. [CrossRef]

54. Lim, J.; Kim, M.Y.; Kim, I.K.; Jung, S.H.; Lim, J.S.; Park, S.Y.; Kim, K.M.; Kim, C.H.; Byun, B.K.; Lee, B.W.; et al. Molecular identification and larval description of Callipogon relictus Semenov (Coleoptera: Cerambycidae), a natural monument of South Korea. J. Asia Pac. Entomol. 2013, 16, 223-227. [CrossRef]

55. Lim, J.; Yi, D.K.; Kim, Y.H.; Lee, W.; Kim, S.; Kang, J.H.; Kim, I.K. Complete mitochondrial genome of Callipogon relictus Semenov (Coleoptera: Cerambycidae): A natural monument and endangered species in Korea. Mitochondrial DNA B 2017, 2, 629-631. [CrossRef] 
56. Simon, C.; Frati, F.; Beckenbach, A.; Crespi, B.; Liu, H.; Flook, P. Evolution, weighting, and phylogenetic utility of mitochondrial gene sequences and a compilation of conserved polymerase chain reaction primers. Ann. Entomol. Soc. Am. 1994, 87, 651-701. [CrossRef]

57. Hall, T.A. BioEdit: A user-friendly biological sequence alignment editor and analysis program for Windows 95/98/NT. Nucleic Acids Symp. Ser. 1999, 41, 95-98.

58. Kumar, S.; Stecher, G.; Tamura, K. MEGA7: Molecular evolutionary genetics analysis version 7.0 for bigger datasets. Mol. Biol. Evol. 2016, 33, 1870-1874. [CrossRef] [PubMed]

59. Excoffier, L.; Laval, G.; Schneider, S. Arlequin (version 3.0): An integrated software package for population genetics data analysis. Evol. Bioinform. 2005, 1, 47-50. [CrossRef]

60. Ronquist, F.; Teslenko, M.; Van Der Mark, P.; Ayres, D.L.; Darling, A.; Höhna, S.; Larget, B.; Liu, L.; Suchard, M.A.; Huelsenbeck, J.P. MrBayes 3.2: Efficient Bayesian phylogenetic inference and model choice across a large model space. Syst. Biol. 2012, 61, 539-542. [CrossRef]

61. Guindon, S.; Dufayard, J.F.; Lefort, V.; Anisimova, M.; Hordijk, W.; Gascuel, O. New algorithms and methods to estimate maximum-likelihood phylogenies: Assessing the performance of PhyML 3.0. Syst. Biol. 2010, 59, 307-321. [CrossRef] [PubMed]

62. Darriba, D.; Taboada, G.L.; Doallo, R.; Posada, D. jModelTest 2: More models, new heuristics and parallel computing. Nat. Methods 2012, 9, 772. [CrossRef]

63. Librado, P.; Rozas, J. DnaSP v5: A software for comprehensive analysis of DNA polymorphism data. Bioinformatics 2009, 25, 1451-1452. [CrossRef]

64. Teacher, A.G.F.; Griffiths, D.J. HapStar: Automated haplotype network layout and visualization. Mol. Ecol. Resour. 2011, 11, 151-153. [CrossRef]

65. Drag, L.; Hauck, D.; Bérces, S.; Michalcewicz, J.; Šerić Jelaska, L.; Aurenhammer, S.; Cizek, L. Genetic differentiation of populations of the threatened saproxylic beetle Rosalia longicorn, Rosalia alpina (Coleoptera: Cerambycidae) in Central and South-east Europe. Biol. J. Linn. Soc. 2015, 116, 911-925. [CrossRef]

66. Drag, L.; Hauck, D.; Rican, O.; Schmitt, T.; Shovkoon, D.F.; Godunko, R.J.; Curletti, G.; Cizek, L. Phylogeography of the endangered saproxylic beetle Rosalia longicorn, Rosalia alpina (Coleoptera, Cerambycidae), corresponds with its main host, the European beech (Fagus sylvatica, Fagaceae). J. Biogeogr. 2018, 45, 2631-2644. [CrossRef]

67. Plewa, R.; Sikora, K.; Gutowski, J.M.; Jaworski, T.; Tarwacki, G.; Tkaczyk, M.; Rossa, R.; Hilszczański, J.; Magoga, G.; Kajtoch, Ł. Morphology, genetics and Wolbachia endosymbionts support distinctiveness of Monochamus sartor sartor and M. s. urussovii (Coleoptera: Cerambycidae). Arthropod Syst. Phylo. 2018, 76, 123-135.

68. Cakmak, Y.E.; Soydabaş-Ayoub, H.K.; Uckan, F. A preliminary phylogenetic analysis of ribbed-pine-borer (Rhagium inquisitor) based on mitochondrial COI sequences. J. Asia Pac. Entomol. 2020, 23, 809-815. [CrossRef]

69. Zhang, Y.; Manzoor, A.; Wang, X. Mitochondrial DNA analysis reveals spatial genetic structure and high genetic diversity of Massicus raddei (Blessig) (Coleoptera: Cerambycidae) in China. Ecol. Evol. 2020, 10, 11657-11670. [CrossRef]

70. Kimura, M. The Neutral Theory of Molecular Evolution; Cambridge University Press: Cambridge, UK; New York, NY, USA, 1983.

71. Hebert, P.D.; Cywinska, A.; Ball, S.L.; Dewaard, J.R. Biological identifications through DNA barcodes. Proc. R. Soc. B 2003, 270, 313-321. [CrossRef]

72. Nakamine, H.; Takeda, M. Molecular phylogeny and phylogeography of flightless beetles Parechthistatus gibber and Hayashiechthistatus inexpectus (Coleoptera: Cerambycidae) inferred from mitochondrial COI gene sequences. Entomol. Sci. 2008, 11, 239-246. [CrossRef]

73. Petit-Marty, N.; Vázquez-Luis, M.; Hendriks, I.E. Use of the nucleotide diversity in COI mitochondrial gene as an early diagnostic of conservation status of animal species. Conserv. Lett. 2020, 14, e12756. [CrossRef]

74. Pruett, C.L.; Winker, K. The effects of sample size on population genetic diversity estimates in song sparrows Melospiza melodia. J. Avian Biol. 2008, 39, 252-256. [CrossRef]

75. Dennis, R.L.H.; Shreeve, T.G. Climatic change and the British butterfly fauna: Opportunities and constraints. Biol. Conserv. 1991, 55, 1-16. [CrossRef]

76. Parmesan, C.; Ryrholm, N.; Stefanescu, C.; Hillk, J.K.; Thomas, C.D.; Descimon, H.; Huntleyk, B.; Kaila, L.; Kullberg, J.; Tammaru, T.; et al. Poleward shifts in geographical ranges of butterfly species associated with regional warming. Nature 1999, 399, 579-583. [CrossRef]

77. Volney, W.J.A.; Fleming, R.A. Climate change and impacts of boreal forest insects. Agric. Ecosyst. Environ. 2000, 82, 283-294. [CrossRef]

78. Hickling, R.; Roy, D.B.; Hill, J.K.; Fox, R.; Thomas, C.D. The distributions of a wide range of taxonomic groups are expanding pole wards. Glob. Change Biol. 2005, 12, 450-455. [CrossRef]

79. Hellmann, J.J.; Pelini, S.L.; Prior, K.M.; Dzurisin, J.D.K. The response of two butterfly species to climatic variation at the edge of their range and the implications for poleward range shifts. Oecologica 2008, 157, 583-592. [CrossRef] [PubMed]

80. Kocsis, M.; Hufnagel, L. Impacts of climate change on Lepidoptera species and communities. Appl. Ecol. Environ. Res. 2011, 9 , 43-72. [CrossRef]

81. Wermelinger, B.; Seifert, M. Analysis of temperature dependent development of the spruce bark beetle Ips typographus (L.) (Col. Scol.). J. Appl. Entomol. 1998, 122, 185-191. [CrossRef] 
82. Yi, D.A.; Kuprin, A.V.; Lee, Y.H.; Bae, Y.J. Newly developed fungal diet for artificial rearing of the endangered long-horned beetle Callipogon relictus (Coleoptera: Cerambycidae). Entomol. Res. 2017, 47, 373-379. [CrossRef]

83. Honda, K.; Akutsu, K.; Arai, S. Photoperiodic response of Acalolepta luxuriosa Bates (Coleoptera: Cerambycidae): Effect of photoperiodic change for induction of larval diapose. Jpn. J. Appl. Entomol. Zool. 1981, 25, 108-112. [CrossRef]

84. Shintani, Y.; Ishikawa, Y.; Tatsuki, S. Larval daiapause in the Yellow-spotted longicorn beetle, Pascothea hilais (Pascoe) (Coleoptera: Cerambycidae). Appl. Entomol. Zool. 1996, 31, 489-494. [CrossRef]

85. Faccoli, M. Effect of weather on Ips typographus (Coleoptera Curculionidae) Phenology, Voltinism, and Associated Spruce Mortality in the Southeastern Alps. Environ. Entomol. 2009, 38, 307-316. [CrossRef]

86. Štefková, K.; Okrouhlik, J.; Doležal, P. Development and survival of the spruce bark beetle, Ips typographus (Coleoptera: Curculionidae: Scolytinae) at low temperatures in the laboratory and the field. Eur. J. Entomol. 2017, 114, 1-6. [CrossRef]

87. Yi, D.A.; Kuprin, A.V.; Bae, Y.J. Effects of temperature on instar number and larval development in the endangered longhorn beetle Callipogon relictus (Coleoptera: Cerambycidae) raised on an artificial diet. Can. Entomol. 2019, 151, 537-544. [CrossRef] 